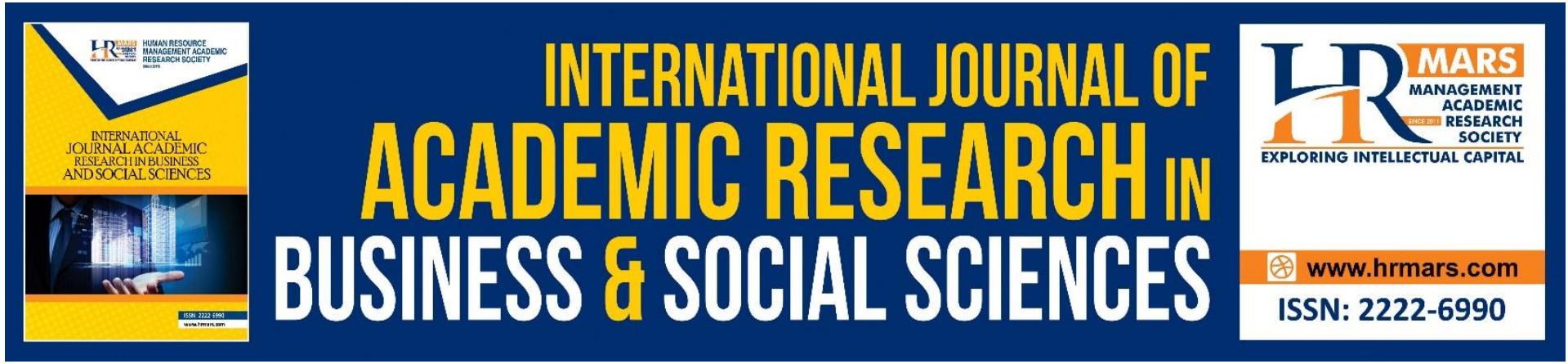

\title{
Visual Rhetoric in Visual Communication: Theory and Concepts in Public Service Announcements Advertising Campaign
}

Muliyati Mat Alim, Rushana Sulaiman @ Abd Rahim

To Link this Article: http://dx.doi.org/10.6007/IJARBSS/v11-i9/11066

DOI:10.6007/IJARBSS/v11-i9/11066

Received: 12 July 2021, Revised: 04 August 2021, Accepted: 25 August 2021

Published Online: 11 September 2021

In-Text Citation: (Alim \& Rahim, 2021)

To Cite this Article: Alim, M. M., \& Rahim, R. S. @ A. (2021). Visual Rhetoric in Visual Communication: Theory and Concepts in Public Service Announcements Advertising Campaign. International Journal of Academic Research in Business and Social Sciences, 11(6), 765-777.

Copyright: (c) 2021 The Author(s)

Published by Human Resource Management Academic Research Society (www.hrmars.com)

This article is published under the Creative Commons Attribution (CC BY 4.0) license. Anyone may reproduce, distribute, translate and create derivative works of this article (for both commercial and non-commercial purposes), subject to full attribution to the original publication and authors. The full terms of this license may be seen

at: http://creativecommons.org/licences/by/4.0/legalcode

Vol. 11, No. 9, 2021, Pg. 765 - 777

Full Terms \& Conditions of access and use can be found at http://hrmars.com/index.php/pages/detail/publication-ethics 


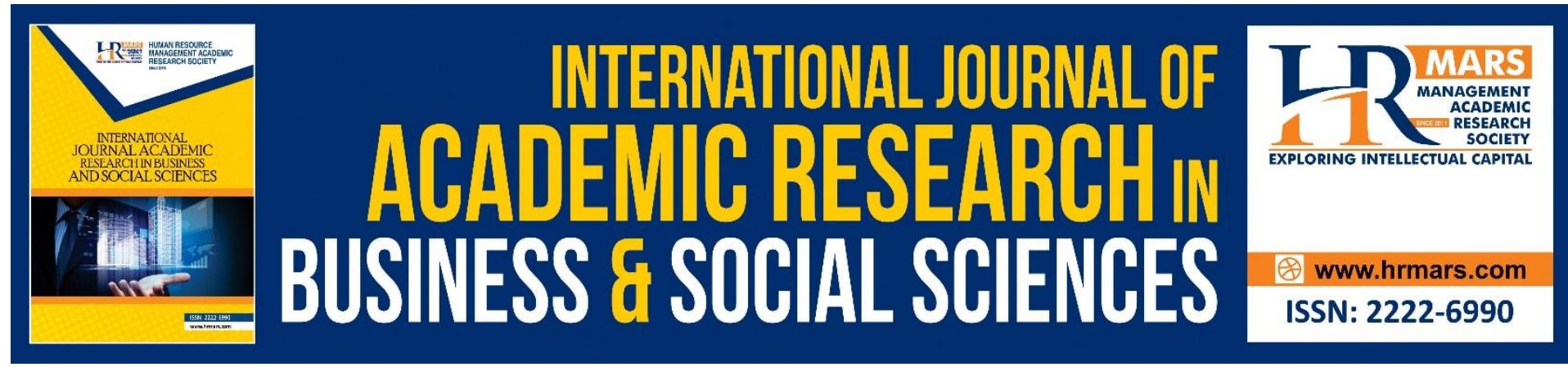

\title{
Visual Rhetoric in Visual Communication: Theory and Concepts in Public Service Announcements Advertising Campaign
}

\author{
Muliyati Mat Alim \\ Faculty of Arts and Social Science, Universiti Tunku Abdul Rahman, Malaysia \\ Email: muliyati@utar.edu.my \\ Rushana Sulaiman @ Abd Rahim \\ Faculty of Art and Design, MARA University of Technology, Malaysia \\ Email: rushana@uitm.edu.my
}

\begin{abstract}
This study discusses the theories, concepts, and also theoretical implications in public service campaign advertisements. There is a basic theory namely semiotics which carries the concept of visual rhetoric and its relationship with several related concepts. Each of the theories and concepts used has an important role in leading to the visual formation and delivery of visual rhetorical meaning to the audience. In this study, theories and concepts are compiled and explained by using public service announcement (PSA) as a case study. As a result of this study, it can be seen that visual rhetoric is explored through the campaign advertisements and becomes the basis of visual communication. Ability in critical thinking becomes an important requirement in exploring and looking at the connections between visual rhetoric in the advertising campaigns of this study. This study can improve high-level thinking skills and also help audience know the need for visual rhetoric in public awareness campaigns.
\end{abstract}

Keywords: Visual Rhetoric, Visual Communication, Advertising, PSA.

\section{Introduction}

Visual communication is a term in the process of conveying information and relating meaning, as stated by Suh (1999). Several key theories are combined to produce a systematic basic concept in understanding the meaning of visual communication. Moriaty (2005), states that this visual communication is part of a combination of fields of thought. In addition, Frascara (1997) mentioned that visual communication is an academic subject that is widely studied covering various fields including communication and rhetoric, psychology, social sciences, and even design. This shows visual communication is an important part of a design to be applied in life and closeness to society, in turn, becomes a social activity. Design critic Kinross (1986) said, "designing, being a social activity, will remain out of reach of formal theory". Dilnot (1989) explains the most important thing about design is to be able to produce, accept and use it seriously in a social context. In addition, design has a functional value, (visual 
communication = convey information) and it also needs to be given attention from the point of view of the study of design.

Burdek (2005), "The [design] discipline's constant crisis of meaning is, in fact, an expression of its increased need for theory and reflection". While the researcher, Lindlof (1998) also said, an interesting basis in communication is the question of rhetoric, construction of meaning (semiotics) in the social context, "The fundamental interest of communication is rhetorical inquiries, the social construction of meaning and semiotics". All these statements lead to the importance of visual communication and rhetoric - semiotics that give meaning also in social contexts. Matters relating to rhetoric and semiotics, are to cover all verbal and non -verbal communication. This is because images are the basic communication elements of the brain while rhetoric and semiotics are the things that bring meaning to those image elements. Thus visual communication is the relationship between images and text including verbal (Damaiso, 1999; Barry, 2002).

The science and art of visual communication require observation. This is because the image will be projected on the right brain, it 'reads' in a different way from the words, while the brain on the left is for processing. In advertising, for example, Carter \& Frith in Barry, 2004 explain, much advertising is designed to exploit the gap or difference between the vulnerable right brain and the more critical left brain. Thus, the ads produced will use visual images rather than words to convey the message.

\section{The Purpose of The Study}

This paper carried out to explores and investigates the existence of the theory and concepts of visual rhetoric in public service announcement campaigns. Concepts of visual rhetoric analysis are conducted to classify component, the characteristic, and symbols interpretation. It also aims to evaluate the implications of the study based on the theory and concepts applied.

\section{Research Methodology}

A qualitative approach uses for this study to focuses on elements, images, and colour in understanding the implementation of visual rhetoric concepts in the PSA campaign. There are two methods of data collection used, which are visual observation, and documentation analysis.

\section{Visual Rhetoric (Semiotic)}

Visual rhetoric can simply give or implicit meaning to a particular visual image. It also describes the culture reflected in the visual. Visual rhetoric is the application of knowledge that focuses on the process of translating symbols into pictures to convey a message or communicate. In 1970 visual images were incorporated into the study of rhetoric through a national conference of rhetoric organized by the Speech Communication Association (Foss, 2005).

In another way, visual rhetoric is also the product of creativity such as a painting, photo, advertisement, or building. Images used as visual rhetoric have a function as a tool of persuasiveness, and aesthetic value. For example, a work of art or an advertisement is not only a communication tool but also must looks attractive. However, not all visual objects are visual rhetoric. There are three main features of visual rhetoric, which is the picture must appear symbolic, second, it involves human intervention, and the last must be shown to the audience to communicate with that audience (Foss, 2005). The three main features of visual 
rhetoric were stated below.

i. Symbolic Action

In visual rhetoric, a picture should go beyond its function as a sign, symbolic, and the picture is indirectly connected to the thing being referred to (Foss, 2005).

ii. Human Intervention

Humans engage in visual rhetoric when it relates to the process of creating a picture. For example, drawing or making a visual recording (photography). This process involves a selection process to make something work such as the selection of colors, shapes, media, and even measurements. This human intervention is also the conversion of non-rhetorical visual images to visual rhetoric. Visual rhetoric requires human action in the process of creation and in the process of interpretation (Foss, 2005).

iii. Presence of Audience

Visual elements produced and modified by designers are not just to express themselves. The other purpose is to communicate with the audience or the community. Designers can be audiences against their designs, but audiences do not have to be rhetoricians or designers (Foss, 2005).

Rhetoric is discussed as the main concept in this study. This provides a broader explanation of the visual characters associated with communication in the study of public service campaign advertisements. An important rhetorical principle underlies this study. Almost all communication is rhetorical, where, it has a persuasive nature in advertising or campaign messages to a specific audience. Magdy (2008) stated visual communication is included in the framework of having rhetoric because it is a persuasion towards people through the use of visuals as well as words. Visual rhetoric can be understood in three things, first, it involves the field of study, second, it is the methods or principles of visual design, and third, it is a type of visual communication. If viewed as a field of study, visual rhetoric is based on the notion of rhetoric not only the study of literature, voice, but culture, art, and even science (Kenney \& Scott, 2003). All of these things require the use of visuals to express or explain something. In addition, actions that describe rhetoric are also included in this context. To see good results in this visual rhetoric, verbal and visual must come together in contributing the ideas and meanings that will result.

To explain the visual rhetoric in this study, a system of signs (semiotics) was used. Barthes (1977) describes a visual image in good advertising will be a statement that has meaning instead. Barthes also further developed two components in this sign system: (i) a signifier (sound, image, or word) and (ii) a signified. These two components become the concept of markers in translating or indicating meaning. Yan and Ming (2015) have also made an explanation of some basic concepts in semiotics by Barthes that play a role in understanding these concepts are reinforced by two mechanisms, natural and general. The use of signs in television, for example, demonstrates a semiotic function that translates meaning in the media from the audience watching. (however, it depends on the level of the audience watching).

Pines in Berger (2013) states this semiotic is the delivery of a message using various types of code. The code is countless, for example in music, gestures, food, religious practices, books, movies, or even advertising. All the codes need to be translated but semiotics teaches humans to find meaning in all objects, images, and so on. Each sign is translated by an object through, looking at the character of the object (referred to as an icon). Then, second, viewed more specifically for the object (known as an index). Third, with the most accurate estimate of the object, it is translated as an indication and referred to as a symbol (Zeman, 1977; 
Berger, 2013). However, there are also limitations in the understanding of meaning. The problem of understanding meaning mostly arises when the relationship between sign appropriateness and meaning is translated arbitrarily without study. Signs can carry many meanings and the meanings will be different to different people.

Tabel 1. Three main features of visual rhetoric in Dragonet Diving - Plastic Bag PSA

\begin{tabular}{|c|c|c|c|}
\hline $\begin{array}{c}\text { Public Service } \\
\text { Announcement ad }\end{array}$ & $\begin{array}{c}\text { Symbolic action } \\
\text { - Signifier } \\
\text { - Signified }\end{array}$ & $\begin{array}{l}\text { Human intervention } \\
\text { (Designer) }\end{array}$ & Presence of audience \\
\hline $\begin{array}{l}\text { Title: Dragonet } \\
\text { Diving - Plastic Bag } \\
\text { (February 2006) }\end{array}$ & $\begin{array}{l}\text { - Signifier - Turtle } \\
\text { image } \\
\text { - Signified- Turtle } \\
\text { image } \\
\text { - Endangered marine } \\
\text { life. } \\
\text {-Image of a turtle, } \\
\text { part of a turtle's } \\
\text { neck on a plastic bag } \\
\text { holder. } \\
\text { - Hand design to } \\
\text { holding a plastic bag } \\
\text { as if holding a turtle } \\
\text { neck. }\end{array}$ & $\begin{array}{l}\text { - Image of a turtle } \\
\text { designed/manipulat } \\
\text { ed vertically, the } \\
\text { green color of a } \\
\text { turtle. } \\
\text { - No background } \\
\text { color, transparent } \\
\text { on plastic bags. } \\
\text { - Black text, the } \\
\text { word 'KILL' is bold, } \\
\text { larger. }\end{array}$ & $\begin{array}{l}\text { Audience viewed: } \\
\text { - Images of turtles } \\
\text { represent endangered } \\
\text { marine life. }\end{array}$ \\
\hline
\end{tabular}

The Implications of Visual Communication and Rhetoric (Semiotics) on Study

The implications of visual communication and rhetoric (semiotic) in this study, are both fundamental in graphic design including public service announcements. Visual communication plays a very important role and can convey certain meanings when used in the visual rhetoric context. Every ads design requires visual rhetoric to convey and deliver a message to target groups, users, and audiences. Visual rhetoric developed from semiotic theory and translated to see meaning through a message example in an advertisement. The selection of images that have rhetorical elements will be able to convey the message quickly and even have a high value of creativity. Creativity is very important for a designer and a good knowledge of visual rhetoric is essential. It will make creativity and evocative in graphic expression and advertising better including public service campaign ads. This visual rhetoric forms symbols, signs, and emblems or icons that necessarily carry a certain meaning. 
Table 1. Shows an example of how a public service campaign ad has two components, signifier and signified and it translates or shows meaning in this ad campaign. The image of the turtle is a signifier and the signified image of the turtle represents endangered marine life. The image of a turtle being strangled by human hands is a marker, interpreted as a symbol of marine life that is dying and about to become extinct with human activities polluting the coast. The designer or creative director turns a picture or image into visual rhetoric. The design is recorded, drawn, or manipulated to communicate with the audience.

\begin{tabular}{|c|c|c|c|}
\hline $\begin{array}{c}\text { Public Service } \\
\text { Announcement ad }\end{array}$ & $\begin{array}{c}\text { Symbolic action } \\
\text { - Signifier } \\
\text { - Signified }\end{array}$ & $\begin{array}{l}\text { Human intervention } \\
\text { (Designer) }\end{array}$ & Presence of audience \\
\hline $\begin{array}{l}\text { Title: Desperate } \\
\text { Animals (Mac 2013) }\end{array}$ & $\begin{array}{l}\text { - Signifier - An image } \\
\text { of an animal is } \\
\text { drawn in the corner } \\
\text { of the paper. } \\
\text { - Signified - facial / } \\
\text { body language } \\
\text { ripples in narrow } \\
\text { angles, fear. } \\
\text { - (Symbol of limited } \\
\text { space in the forest). } \\
\text { - No color (symbolic } \\
\text { of bad condition, } \\
\text { uncomfortable, sad, } \\
\text { blurred). }\end{array}$ & $\begin{array}{l}\text { - Images of animals } \\
\text { are designed/drawn } \\
\text { in the corners of the } \\
\text { paper / torn into } \\
\text { pieces of paper } \\
\text { (real paper torn } \\
\text { effect). } \\
\text { - Designers create } \\
\text { images of facial } \\
\text { expression animals. }\end{array}$ & $\begin{array}{l}\text { Audience viewed: } \\
\text { - Images of animals in } \\
\text { the corners of the } \\
\text { paper. } \\
\text { - Images of frightened } \\
\text { animals. } \\
\text { - Titles help the } \\
\text { audience to } \\
\text { understand the } \\
\text { image. }\end{array}$ \\
\hline
\end{tabular}

Tabel 2. Three main features of visual rhetoric in Desperate Animals PSA

Table 2 is another advertisement in the form of a print advertisement that conveys the message about deforestation resulting in the original habitat of wild animals being affected. Symbolic in this campaign ad is on the images used. It is carefully drawn. The painter is skilled in fine art and arranged in every corner of the poster. However, these posters were exhibited at an early stage separately. This is because the theme or concept used is a space element. Each wild animal is drawn in a corner and the space is too narrow. The facial expressions as well as the body language displayed on each animal symbolize the message conveyed by the advertiser, namely "Desperate animals". The original living space or habitat i.e., the forest that has been explored, the trees cut down, makes the animals increasingly desperate to seek shelter. 
Tabel 3. Three main features of visual rhetoric in Cut A Tree. Kill A Life PSA

\begin{tabular}{|c|c|c|c|}
\hline $\begin{array}{c}\text { Public Service } \\
\text { Announcement ad }\end{array}$ & $\begin{array}{c}\text { Symbolic action } \\
\text { - Signifier } \\
\text { - Signified }\end{array}$ & $\begin{array}{l}\text { Human intervention } \\
\text { (Designer) }\end{array}$ & Presence of audience \\
\hline $\begin{array}{l}\text { Title: Cut A Tree. } \\
\text { Kill A Life (Mac } \\
\text { 2015) }\end{array}$ & $\begin{array}{l}\text { - Signifier - Image of } \\
\text { an animal on the } \\
\text { surface of a tree, an } \\
\text { image of blood flow. } \\
\text { - Signified - Image of } \\
\text { a blood-red animal, } \\
\text { flowing from a tree } \\
\text { trunk. (effect) of } \\
\text { deforestation. }\end{array}$ & $\begin{array}{l}\text { - Images of animals } \\
\text { are designed on the } \\
\text { surface of the tree. } \\
\text { - Digitally painted } \\
\text { 2D, concise style. }\end{array}$ & $\begin{array}{l}\text { Audience viewed: } \\
\text { - Images of animals on } \\
\text { the surface of trees } \\
\text { and blood red. } \\
\text { - Images of animals } \\
\text { from tree trunks. } \\
\text { (deforestation). } \\
\text { - The title helps the } \\
\text { audience understand } \\
\text { the message of the } \\
\text { Ad. }\end{array}$ \\
\hline
\end{tabular}

Table 3 is the visuals that are symbolic in this campaign, drawn digitally using computer software. Designers who are skilled in digital drawing software and skilled in matching the images used. Simple image design and four series of ads with different animal images. Animal visuals are designed by combining two different images of animals and trees that have been cut down. This has 'symbolized' the message that the advertiser wants to convey, namely 'Cut A Tree. Kill A Life'. When deforestation is happening without control then it will kill other life in it. The original habitat or habitat of wild animals (forests that have been explored), trees have been cut down, making the animals seek refuge and eventually die. All these images of animals are designed and shown with traces of flowing blood. This is symbolic of the killing and even the death of wildlife in the forest. Hence, the image or symbol in this study is visual rhetoric and it goes beyond its function as a sign (symbol) also to the audience.

\section{Ethos, Pathos and Logos}

Ethos, Pathos, and Logos are a set of persuasive concepts used to persuade or influence an audience. The term is derived from a Greek word by Aristotle then widely used in the field of art especially advertising to this day.

\section{i) Ethos}

Ethos or ethical appeal, used in the field of advertising for example to show the audience the credibility of an advertisement or campaign. This is important in persuasion to the audience. Apart from that, it also shows the credibility of the writer or presenter of the advertisement, and it has value. The original Greek term, Ethos means character. In addition, the word 'ethics' used until now comes from the word Ethos. In most other debates, this Ethos is often presented by experts in a particular field. In the field of advertising, for example, advertisers will use celebrities who are famous because of the celebrity's credibility (Detisch, 2018). Meaning the Ethos will be visible through the selection or involvement of celebrities in the advertisement. However, not all celebrities have the knowledge and expertise in the products or advertising campaigns that involve them. This is because most of them are only paid for advertising. So, when using Ethos in advertising, it is significant to ensure who will be involved and what elements will be used so that the ad or campaign can be trusted and have credibility (Newbold, 2013). For this, public service campaign advertisements were included. It's the 
importance of caring by advertisers (NGOs or associations that have authority and are registered) as well as the elements used to be a factor in the audience's trust.

ii) Pathos

Pathos is an emotional attraction where it is also used to persuade the audience in advertising. Writers, presenters, or advertisers use Pathos to attract sympathy and delve into what is conveyed in the message. Usually, Pathos will evoke or produce a sense of sympathy or emotion from the audience. The same goes to when this emotional appeal is used in public service announcement campaigns. For example, the audiences will have some emotional feeling for the consequences that have to be borne by wild animals due to forest destruction. Moreover, Pathos can be developed using language that carries meaning, emotional tones, provocations, emotions in the storyline as well as in symbolism (Newbold, 2013). Most of the ads are very good at using this emotional appeal to affect the audience especially the humorous ones. It has a positive emotional impact on a product or issue and can elicit a response whether the audience buys or gives support.

iii) Logos

Logos are the appeal of logic or the use of logic and reason to persuade an audience. The use of these Logos indicates facts and perhaps even statistics, history, analogies, and characteristics of a subject (Newbold, 2013). Logos is also a term from the Greek word 'logic'. It can be developed in more depth with certain theoretical clarity even if abstract. But the thing most emphasized is the facts that lead to sound logic and argumentation. This is because it will be strong evidence to persuade or influence the audience with what is presented or advertised. However in advertising or message delivery, to support the fact of using Logos alone is not sufficient. To complete the persuasion of the audience, the presenter or advertiser needs to use topic relevance through Pathos and the audience should feel and believe in the information through Ethos. So these three concepts are indispensable in visual rhetoric for good results or arguments in advertisements or campaigns and so on.

\section{Persuasion in Advertising}

Persuasion in advertising is the technique that allows advertisers to influence an audience with their product or message. Especially by using visuals and this can be done with ethos, pathos, and logos. According to Newbold (2018), it is also known as The Rhetorical Triangle. Ethos is associated with a presenter who is credible, trustworthy, and has good ethics. Pathos in turn is associated with the audience because of the emotional appeal required in this concept. Emotions that should be felt or want to be felt by the presenter towards the audience. Then the Logos is associated with the message to be conveyed. It should include facts, truth, and logic.

The same goes for the advertising messages that necessarily convey good information, the truth, and can be accepted by the audience. Moreover, in advertising, these three concepts are important to produce good ad design. Public service announcements (PSA) are one of the types of advertisements that are significant to the community. Thus, the use of Ethos, Pathos, and Logos in advertisements is important in conveying the message of gain awareness. 


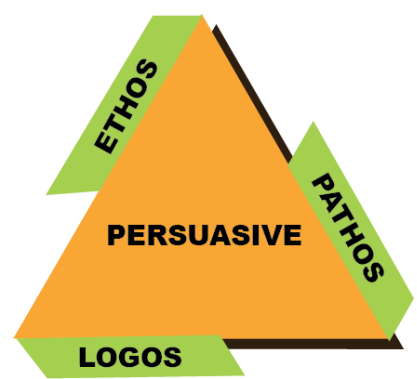

Figure 1. Diagram of Persuasive based on Ethos, Pathos and Logos adaptation from The Rhetorical Triangle (Newbold, 2018).

Figure 1 above is a rhetorical triangle showing the relationship between Ethos, Logos, and Pathos used in advertising as well as marketing by Newbold (2018). This relationship involves the advertiser as the Ethos, the message as the Logos, and the audience as the Pathos. It has been explained before that when the three main concepts above are used together then persuasion of the audience or user will be occured. This persuasion becomes an important factor in determining the message being conveyed will stimulate action from the audience or user.

\section{Implication of Ethos, Pathos and Logos on the Study}

The implication of this concept in this study is to further clarify the translation of visual rhetoric in this public service announcements advertisement. This is because visual rhetoric is often used in advertising to persuade the audience. Good visual rhetoric contains Ethos, Pathos, and Logos. Every ad design should have the credibility or ethics that the advertiser represents to deliver the message. This is in the concept of Ethos. Pathos is an emotional attraction that is needed for the audience to feel an emotion in each advertising message. Then, the Logos states the concept of truth, facts, and even logic in the message to be conveyed. Important appropriate images selection as well to apply this concept. In addition, the high value of creativity in each advertisement can be seen if this concept is applied included in the public service announcements advertisement.

\section{Awareness, Instruction, and Persuasion}

Public service announcements ads or PSAs should contain three types of messages to influence or change behavior. It is awareness, instruction, and persuasion. To create awareness, each message in the campaign must be focused on the right target group. In giving instructions, message must be directed to the group based on the needs and the process how it will be done. Then in persuasion, message should persuade to the right target group.

According to Atkin (2010), the message in a public service campaign should be clear about what is to be conveyed, inform the target group, and state the process of each action that needs to be taken. Message that is tried to be conveyed will exactly meet the purpose of delivering. Dervin and Frenette (2001) state the same thing as Atkin and Freimuth (2001) about the effectiveness of the campaign message will be increased if the message is specifically addressed to the specific target group.

The design of a campaign begins with the concept of seeking opportunities and has the challenge of identifying behaviors from different people (Atkin \& Salmon, 2010). Then, it begins by identifying what is closest or best to produce a model in influencing behaviors, beliefs, social and environmental influences. The next step tests the model from the perspective of communication, specific target groups, and target group behaviors that will 
influence through campaign messages (Atkin \& Rice, 2013). Hence, in this public service announcements advertisement, it is important to identify the target, place, and form of the theme that fits the message before reach to community.

In influencing the behavior of the target group, most campaigns are efforts to promote good behavior. These include healthy eating campaigns, safety belts, recycling, environmental awareness, or campaigns to address health problems. Most campaigns are normally call on the community to prevent negative things or campaigns promoting good effects as an alternative. To improve or develop such advertisements, a designer should produce advertisements that show a good example or picture (Philip, Roberto, \& Lee, 2002). In delivery of the messages, the content of the message is divided into two things, namely informative and persuasive. In most campaign advertisements, the informational message is to generate awareness or provide guidance for the community to play a specific role. This message in the form of awareness contains a simple message to tell the community what needs to be done, in more detail including time and place. Sometimes the message invites the public to find better or complete information by getting a book, browsing the website, or even contacting certain parties. If the message to be conveyed is more complex then it requires better message content including the use of appropriate images, knowledgeable content, and the right media selection.

However, the main thing in every ads campaign is a persuasive appeal. This means that every ads campaign should combine message and persuasion. The purpose is to encourage, invite and avoid rejection from the community or consumers. This behavior is aided by the presence of knowledge and trust. Audiences who readily receive campaign advertising messages are also easy to encourage, invite and even persuade to get involved. The selection of campaign time intervals can also help in influencing an audience, consumer, and community behavior. Every advertising campaign to give awareness, give instructions and persuade the community in caring for the environment for example is a matter that requires continuous measures and efforts. Each message should be conveyed to the community because they also have experience in the things that are the visual elements of rhetoric (symbols, signs, or emblems) for the delivery of the message.

\section{Implication of Awareness, Instruction, and Persuasion on study}

Implications of Awareness, Instruction, and Persuasion in this study, is this concept used in helping designers and audiences to understand and have some perceptions on graphic design, advertising, and public service campaigns. This perception is important for determining how the designer or audience understands and translates the meaning behind a particular public service announcements ad. It is much related to one's experience and helps in making perceptions. Public service announcement or PSA should contain these three types of components intended to influence behavior change. Awareness, instruction, and persuasion. Perception triggers awareness and should be every message in a campaign that can deliver to the audience. The same goes for the designer should have a perception that can produce designs in giving awareness to the audience who sees the campaign advertisement.

\section{Application of Visual Rhetoric in Advertising}

Important to understand how visual-semiotic rhetoric is applied or used in visual communication especially in the field of advertising. An understanding of communication, visual communication, and also the designer who produces the design is important since they are interrelated. 
From the beginning, the communication associated with these semiotic rhetoric's will be involved with signs and codes. John Fiske in Introduction Communication Studies (2010), there mentions a sign is an action that refers to a message carried while a code is an organized sign system. It determines how the signs intersect with each other. For example in our daily lives, if observed on the road that is marked various signs including traffic lights as a determinant of the sign into the code system. Signage and traffic lights are a systematic group of signs as an arrangement of signs for use in a code system (convention/pattern/formula). The second thing that needs to be understood is visual communication is communication using visual language, being the main strength in conveying complete communication. It is something that can be seen and worn to convey meaning or message. Looking to detail, the next thing that needs to be understood is the design in visual communication is the knowledge that learns about the concept of communication and creativity, techniques, and media to convey a message and a visual idea. This includes audio by processing graphic design elements such as shape, appearance, image, typography, color, and layout. This considers effective when the message and design can be accepted by its target group. This process of creativity is a method in producing designs. Again, it requires a designer or group of designers to find the solution in problem-solving of visual communication by producing a design that affects the audience.

In general, a designer performs a process of communication addressed to the target group through the work (advertisement) he produces. Using a variety of creative media and mediums, a designer will translate a message from an advertiser in various forms of signs (symbolic) addressed to a target group based on a specific pattern (code system) then the advertising work will be published or commercialized. The translation of a message from an advertiser using certain signs or symbols in the ad design is referred to as the encoding process. Then this design brings the verbal and visual message creatively and effectively to the user and expects the meaning of the message to be the same or reach as expected by the advertiser.

Communication involves several things as follows; 1 . source 2. encoding 3. message 4. message channel 5. Receiver 6. interpretation 7. noise 8. feedback (Kismiaji, 2008). The use and application of visual-semiotic rhetoric in the design of visual communication can be seen from the methods and ideas to ensure the message communicate using signs as the main element in the design. Signs are produced in the form of verbal and non -verbal signs produced by a designer where verbal signs are speech, voice, or writing. While non -verbal (visual) signs are pictures that correspond to the message to be conveyed. Kismiaji (2008) also said that the message delivered by the advertiser will always contain some markers either in the form of mere writing or pictures that lead to the same meaning. This will produce several signs (representations) that lead to an interpretation called symbolism.

\section{Implications of the Application Visual Rhetoric in Advertising}

The implication of the application of visual rhetoric in advertising is the theory and concept allows all types of ads design to be created, viewed, read, and translated well either by the designer or the audience. This application plays a very important role, allowing each image to illustrate meaning by being used in the form of visual rhetoric and giving maximum impact.

Every ads design requires the application of visual rhetoric to convey a message to the target group i.e. the community. A good ad will contain precise visual rhetoric through the use of images, text, and other elements that help the message be translated. An appropriate 
application of rhetoric will convey the message quickly and have a high value of creativity. It is important for a designer to have a good knowledge of visual rhetoric and applied in advertisements and it will increase the creativity and evocative in design expression. So this study well guides as a reference for the application of rhetoric in advertising.

\section{Conclusion}

In conclusion, theory and concepts in visual rhetoric become important elements of connecting symbols with messages to be conveyed to the audience. Symbols from images as well as text used in campaign ads carry a specific message to the target audience. Cheung (2011) explains all types of design, including advertising design, are about meaning. Solik (2014) states that advertisements work in the way they influence recipients. Albakry (2014) and Peterson (2017) stated that visual rhetoric is an important element to increase the effectiveness in conveying the message to the audience and metaphors are presented in any advertisement and are often produced entirely through visuals.

Exploration and interpretation findings in this study can be seen that the use of the good concept of visual rhetoric can produce campaign ads with a more meaningful and clearer message to the audience. In today's world of communication, visual communication is seen to be more effective if it has elements that symbolize certain meanings.

\section{References}

Atkin, C., \& Salmon, C. T. (2010). Communication campaigns.na.

Atkin, C. K., \& Rice, R. E. (2013). Theory and principles of public communication campaigns. Public communication campaigns, 4, 3-20.

Barrett, T. (2006).Criticizing Photographs, an introduction to Understanding Images, Edisi4.,NewYork: McGrawHill.

Barthes, R. (1977). Image Music Text (selected and translated by Stephen Heath). London: Fontana.

Barry, A. M. (2002). Perception and visual communication theory. Journal of Visual Literacy, 22(1), 91-106.

Barry, A. M. (2004). Perception theory (pp. 67-84). Routledge.

Bernard, H. R. (2002). Qualitative data analysis I: text analysis. Research methods of anthropology, 440-448.

Bogdan, R. C., \& Biklen, S. K. (2006). Qualitative research in (validation) and qualitative (inquiry) studies. It is a method-appropriate education: An introduction to theory and methods.

Bürdek, B. E. (2005). Design. Birkhäuser.

Cheung, W. S., \& Hew, K. F. (2011). Design and evaluation of two blended learning approaches: Lessons learned. Australasian Journal of Educational Technology, 27(8).

Dervin, B., \& Frenette, M. (2001). Sense-making methodology: Communicating communicatively with campaign audiences. Public communication campaigns, 3, 69-87.

Detisch, A. J. (2018). Ethos, Pathos \& Logos: Persuasive Advertising Techniques of 2018. https://www.studiobinder.com/blog/ethos-pathos-logos/

Dilnot, C. (1989). The state of design history. MARGOLIN, Victor.

Fiske, J. (2010). Introduction to communication studies. Routledge.

Foss, S. K. (2005). Theory of visual rhetoric. Handbook of visual communication: Theory, methods, and media, 141-152. 
Frascara, J., Meurer, B., van Toorn, J., \& Winkler, D. (1997). User-centred graphic design: Mass communication and social change. CRC Press.

Freimuth, V., Cole, G., \& Kirby, S. (2001). Issues in evaluating mass media-based health communication campaigns. Consulté à http://www. dors. it/marketing_sociale/docum/Eval_Media_Campaign_WHO.pdf.

Kismiaji, S. (2008) Semiotika Pemanfaatan dan Penerapannyaișpipada Desain Komunikasi Visual, http://islamicgraphicdesign.blogdetik.com/2008/12/31/semiotika-dan-desainkomunikasi-visual/

Lindlof, T. R., \& Shatzer, M. J. (1998). Media ethnography in virtual space: Strategies, limits, and possibilities. Journal of broadcasting \& electronic media, 42(2), 170-189.

Madgy, M. (2008). A semiotic phenomenology of visual rhetoric: Communication and perception of attributes of cultural sustainability in the visual environment of public housing (Doctoral dissertation, North Carolina State University).

Moriarty, S. (2005). Visual semiotics theory. Handbook of visual communication: Theory, methods, and media, 8, 227-241.

Newbold, C. (2013). Visual Rhetoric and The Concepts. thevisualcommunicationguy.com/2014/02/13/what-is-visual-rhetoric/

Newbold, C. (2018). The Rhetorical Triangle. thevisualcommunicationguy.com/2014/02/13/what-is-visual-rhetoric/

Albakry, N. S., \& Daimin, G. (2014). The visual rhetoric in public awareness print advertising toward Malaysia perceptive sociolculture design. Procedia-Social and Behavioral Sciences, 155, 28-33.

Peterson, M., Wise, K., Ren, Y., Wang, Z., \& Yao, J. (2017). Memorable metaphor: How different elements of visual rhetoric affect resource allocation and memory for advertisements. Journal of Current Issues \& Research in Advertising, 38(1), 65-74.

Kotler, P. N. R., \& Lee, N. (2002). Social Marketing: Improving the quality of life. California: Sage Publications, Inc, 13, 10-15.

Solík, M. (2014). Semiotic approach to analysis of advertising. European Journal of Science and Theology, 10(1), 207-217.

Suh, T. (1999). What are the Visual Aspects in Communication. Communication Research Trends, 19(3), 4-18. 